\title{
Spontaneous pneumomediastinum: report of two cases
}

\author{
Spontan pnömomediastinum: İki olgu sunumu
}

\author{
Çağatay TEZEL, ${ }^{1}$ Pınar VARER, ${ }^{1}$ Volkan BAYSUNGUR, ${ }^{1}$ Erdal OKUR, ${ }^{2}$ Semih HALEZEROĞLU ${ }^{2}$
}

Spontaneous pneumomediastinum (SPM) is an uncommon, benign, self-limited disorder that usually occurs in young adult males without any apparent precipitating factor or disease. SPM responds extremely well to conservative treatment, without recurrence in the great majority of cases. In this report, two patients who were admitted for SPM are discussed together with the associated literature.

Key Words: Mediastinum; mediastinal emphysema; spontaneous pneumomediastinum.
Spontan pnömomediastinum (SPM) nadir, çoğunlukla genç erkeklerde görülen, zemin hazırlayan faktör bulunmayan, ya da altta yatan sebebi bulunmayan selim bir hastalıktır. SPM konservatif tedaviye oldukça iyi yanıt verir ve tekrarlama riski oldukça düşüktür. Çalışmamızda, kliniğimizde yatırılarak takip edilen iki SPM olgusu literatür eşliğinde tartışıldı.

Anahtar Sözcükler: Mediasten; mediastinal amfizem; spontan pnömomediastinum.
Mediastinal emphysema or pneumomediastinum is the presence of air within the confines of mediastinal structures. Mediastinal emphysema was first described by Laennec ${ }^{11]}$ in 1819 , and spontaneous mediastinal emphysema was first reported by Hamman ${ }^{[2]}$ in 1939. The main causes of mediastinal emphysema include trauma, iatrogenic factors, infections, and esophageal rupture occurring after severe vomiting. Spontaneous pneumomediastinum (SPM) is a rare clinical condition typically observed in young males; frequently, this condition occurs with no obvious underlying cause. ${ }^{[3]}$

Two cases of SPM are presented with respect to clinical and radiological findings and are discussed in light of the related literature.

\section{CASE REPORTS}

Case 1- A 33-year-old male patient presented to our clinic for dyspnea. He had a history of asthma for 20 years and intermittently received bronchodilator treatment; however, he suffered from increased dyspnea during the last 10 days. On physical and routine laboratory examinations, no abnormal findings were revealed.
His chest X-ray demonstrated a linear doublecontour along the cardiac border of the left mediastinal pleura. The patient was hospitalized to monitor for possible SPM. Thorax computerized tomography (CT) revealed air around the mediastinal vessels that separated vascular structures from adjacent soft tissues (Fig. 1a, b). Oxygen and bronchodilators were administered. His condition improved both clinically and radiologically within two days after admission. He was discharged immediately after improvement. No problem was observed during the follow-up period.

Case 2- A 21-year-old male patient presented to our clinic with dyspnea that developed within the last two days. His medical history included a traffic accident 10 years before. Physical examination revealed limited subcutaneous emphysema of the neck and left side of the thorax. Routine laboratory test results were within normal limits.

Chest X-ray revealed a linear air shadow along the cardiac border in the left mediastinal region (Fig. 2a). CT detected subcutaneous emphysema on his neck and left side of the thorax accompanied by mediastinal

\footnotetext{
${ }^{1}$ Sureyyapasa Chest Diseases and Thoracic Surgery Training Hospital, Istanbul; ${ }^{2}$ Department of Thoracic Surgery, Acıbadem University, Istanbul, Turkey.
}

${ }^{1}$ Süreyyapaşa Göğüs Hastalıkları ve Göğüs Cerrahisi Eğitim ve
Araştırma Hastanesi, İstanbul;

${ }^{2}$ Acıbadem Üniversitesi, Gögüüs Cerrahisi Kliniği, İstanbul. 

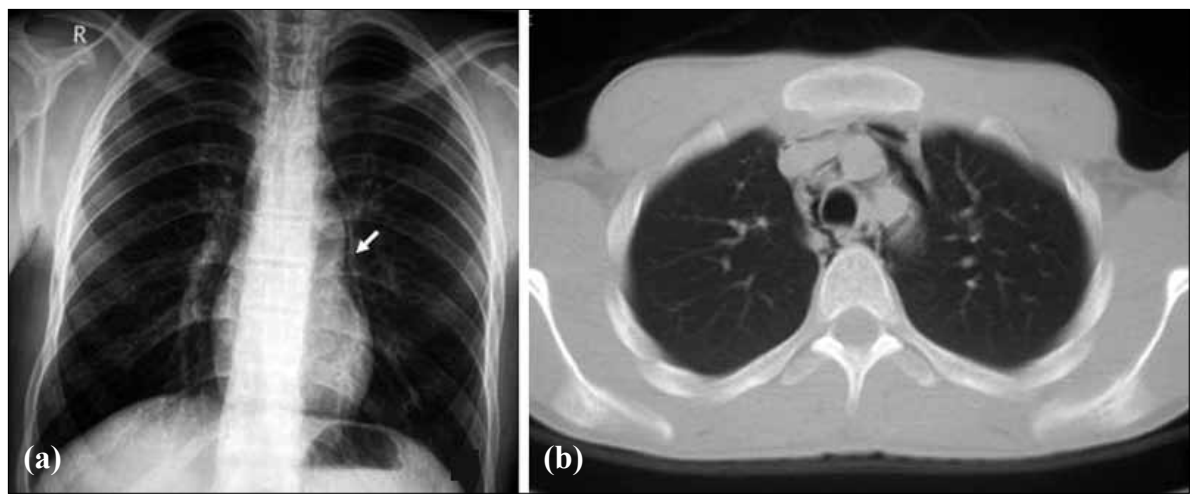

Fig. 1. (a) Linear double-contour along the cardiac border of the left mediastinal pleura on plain chest X-ray. (b) Computed tomography shows mediastinal emphysema.

emphysema (Fig. 2b). The patient was hospitalized for SPM. Nasal oxygen was administered. He was discharged on the fifth day of follow-up as his findings of pneumomediastinum had improved both radiologically and clinically.

\section{DISCUSSION}

SPM is a rare clinical disorder frequently observed in young males without obvious underlying causes. There are only case reports and small case series in the literature; thus, the exact incidence of SPM is unknown. However, Newcomb and Clarke ${ }^{[4]}$ reported the incidence of SPM as $1 / 29,670$ in their study. Macklin and Macklin $^{[5]}$ first described the pathophysiology of SPM in 1944 according to results of their animal study, and they pointed to terminal alveolar rupture as the primary pathology; further, dissection of air through the hilum due to the pressure gradient caused by increased alveolar pressure or decreased perivascular interstitial pressure was described as the secondary pathology. Less frequent but important causes include tracheobronchial or esophageal rupture and facial fractures that lead to disruption of maxillary sinus walls and create a communication between the paranasal sinuses and connective tissues of the neck.
SPM usually follows coughing, vomiting, intense exertion, and Valsalva maneuvers, all of which cause sudden increase in intra-alveolar pressure without specific cause such as trauma. Studies have also reported its association with cocaine and marijuana use and the presence of asthma. ${ }^{[6,7]}$ In the first case, asthma might have been the primary etiological factor. However, no obvious preceding events or factors were detected in the second case, as is the case in nearly $20 \%$ of all mediastinal emphysema patients. ${ }^{[6]}$

Chest and neck pain, dyspnea, subcutaneous emphysema, hypotension, dysphagia, and cough are common SPM symptoms. Chest pain is characteristically sudden and pleuritic, and may radiate to the back and shoulders. Subcutaneous emphysema has a prevalence ranging from $40 \%$ to $100 \%,{ }^{[7]}$ and occurs when intrathoracic air leaks into the soft tissues after pneumothorax or pneumomediastinum. Hamman's sign is another clinical finding of SPM and was described by Hamman; it is defined as the crepitation detected at the time of the apex beat during cardiac auscultation.

Diagnosis is established by anteroposterior and lateral chest X-rays. Similar to the cases presented in this study, simple radiological examination is sufficient
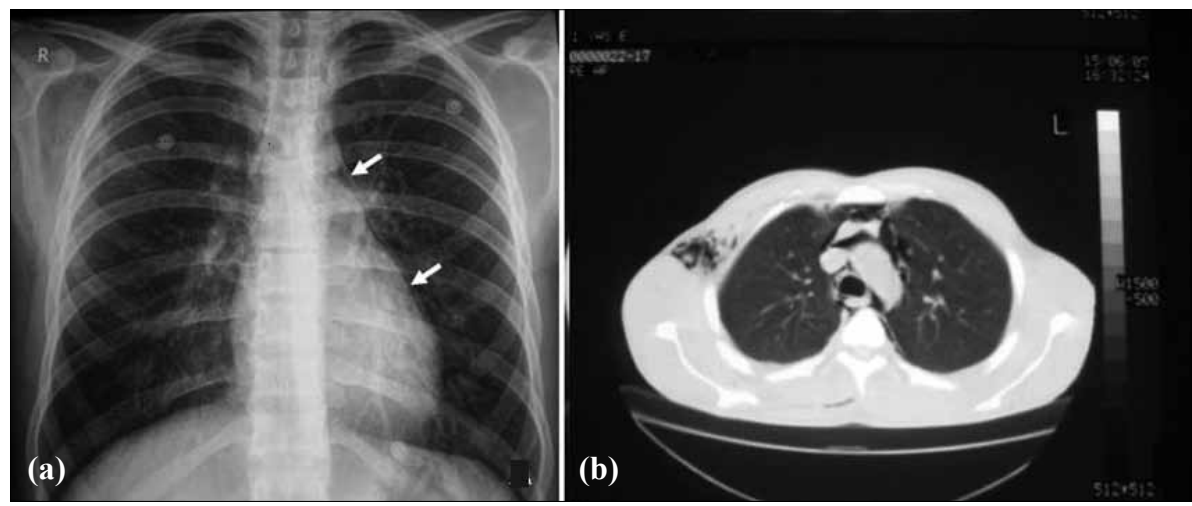

Fig. 2. (a) Chest X-ray shows a linear air shadow along the cardiac border in the left mediastinal region with right subcutaneous emphysema. (b) Computed tomography depicts subcutaneous emphysema on the neck and left side of the thorax along with mediastinal emphysema. 
in nearly all SPM cases. Thus, Yellin et al. ${ }^{[8]}$ recommends a routine chest $\mathrm{X}$-ray for all young patients that present to emergency departments with chest pain and dyspnea. The chest radiograph shows vertical linear collections of air in the mediastinum. The combined parietal and visceral layers of the mediastinal pleura appear as a hairline shadow running parallel to the mediastinal and cardiac contours, which is the best diagnostic clue. The differential diagnosis includes pneumopericardium in the first step. Pneumopericardium is less common in the young-adult population, and the key feature is the air around the base of the heart, which is less frequent in pneumomediastinum. Others pathologies in the differential diagnosis are airdistended esophagus, or achalasia, and pneumonia in the lateral region of the lower lobes.

If X-ray findings are not sufficient for diagnosis, additional examinations such as $\mathrm{CT}$ or esophagogram may be considered to rule out perforations. CT is highly accurate in detecting pneumomediastinum, especially in cases with tracheobronchial or esophageal rupture. Electrocardiography may reveal reduced voltage, ST segment changes or axis deviations in some cases. ${ }^{[9]}$

Primary SPM can be treated easily after all other causes of mediastinal emphysema are excluded. However, this condition has the potential for severe complications. Increased mediastinal pressure may lead to tension pneumomediastinum that may be fatal.

If SPM diagnosis is established, the patient should be hospitalized for a minimum of 24 hours to prevent potential complications. ${ }^{[6]}$ Treatment includes bed rest and analgesic and oxygen administration; mediastinal emphysema usually resolves within several days.

Malignant pneumomediastinum is a life-threatening condition characterized by presence of excess air in the mediastinum; subcutaneous aspiration and incisions may be required to evacuate excess air. Cervical mediastinotomy may be performed if aspiration proves to be insufficient. ${ }^{[10]}$ This type of decompres- sion is life-saving in many pneumomediastinum patients.

The two hospitalized cases did not develop any complication throughout the follow-up. No antibiotic was administered as no signs of infection were demonstrated.

To conclude, prognosis of mediastinal emphysema depends on the trapped air in the mediastinum and its etiology. Spontaneous cases should be hospitalized to prevent potential complications. SPM shows a benign course and usually does not require additional treatment; however, patients should be kept under observation.

\section{REFERENCES}

1. Laennnec RTH. A treatise on diseases of the chest on mediate auscultation. Translated by John Forbes. 2nd ed. London: T\&G Underwood; 1819.

2. Hamman L. Spontaneous mediastinal emphysema. Bull John Hopkins Hosp 1939;64:1-21.

3. Ralph-Edwards AC, Pearson FG. Atypical presentation of spontaneous pneumomediastinum. Ann Thorac Surg 1994;58:1758-60.

4. Newcomb AE, Clarke CP. Spontaneous pneumomediastinum: a benign curiosity or a significant problem? Chest 2005;128:3298-302.

5. Macklin MT, Macklin CC. Malignant interstitial emphysema of the lungs and mediastinum as an important occult complication in many respiratory diseases and other conditions: an interpretation of the clinical literature in the light of laboratory experiment. Medicine 1944;23:281-358.

6. Weissberg D, Weissberg D. Spontaneous mediastinal emphysema. Eur J Cardiothorac Surg 2004;26:885-8.

7. Koullias GJ, Korkolis DP, Wang XJ, Hammond GL. Current assessment and management of spontaneous pneumomediastinum: experience in 24 adult patients. Eur J Cardiothorac Surg 2004;25:852-5.

8. Freixinet J, García F, Rodríguez PM, Santana NB, Quintero CO, Hussein M. Spontaneous pneumomediastinum longterm follow-up. Respir Med 2005;99:1160-3.

9. Yellin A, Gapany-Gapanavicius M, Lieberman Y. Spontaneous pneumomediastinum: is it a rare cause of chest pain? Thorax 1983;38:383-5.

10. Abolnik I, Lossos IS, Breuer R. Spontaneous pneumomediastinum. A report of 25 cases. Chest 1991;100:93-5. 